\title{
Covid-19: Japan declares state of emergency as Tokyo cases soar
}

\author{
Mun-Keat Looi
}

London

Japan has declared a month long state of emergency in seven major prefectures after a spike in the number of covid-19 cases.

The largest rises are in the Tokyo metropolitan area, which saw the number of cases double in five days to over 1000 (now standing at nearly 1400). On 9 April Japan had a total of 5002 official cases (excluding 712 cases on the Diamond Princess cruise ship), 116 deaths, and 1270 recovered (including on the Diamond Princess), according to public broadcaster NHK.

On 7 April, Prime Minister Shinzo Abe declared a state of emergency until 6 May in Tokyo and the neighbouring Chiba, Saitama, and Kanagawa prefectures, Hyogo, and the industry and business hubs of Osaka and Fukouka.

Abe said that the aim was to reduce social contact with others by at least $70 \%$, ideally $80 \%$, which could see the country curb the peak of infections in two weeks. He called on citizens to show the community spirit of the March 2011 tsunami. "The bonds that formed between people gave us hope. We are again facing a crisis, but if we work together, we will rise to the challenge and defeat this virus," he said.

The measures-enabled by emergency powers granted to the Japanese government on 13 March-allow prefectural governments to ask residents to stay at home, to request or order the closure of schools, and to restrict places where people gather such as cinemas and museums. The government will also send two reusable cloth masks each to 50 million households across the country, as well as care homes and schools, to counter a nationwide mask shortage. ${ }^{2}$

Schools across the country have already been closed since 2 March and were due to reopen with the start of the new school year in early April. Though some have since reopened, many remain closed.

Under Japanese law private companies cannot be forced to close nor can citizens be forced to stay indoors or penalised for not doing so. But the declaration has seen a temporary closing of stores and encouragement of home working, although reports of packed commuter trains remain common.

Supermarkets, pharmacies, and public transport remain open. The state of emergency allows prefectural governments to request delivery firms to transport medical goods and equipment, including masks. Land and buildings can be used without the consent of the owners for temporary medical facilities, and governors can order the storage of essential goods, such as medicine.
Ahead of the state of emergency, Tokyo governor Yuriko Koike had already asked residents to refrain from socialising outside of work hours and to stay at home on the past two weekends after reports of citizens flocking to restaurants and parks for the traditional spring cherry blossom viewings. Koike is in negotiations with the national government to clarify a list of which businesses should close and which can stay open.

Although Japan had seemingly avoided the worst of the pandemic, the Japanese government had been under increasing pressure from local leaders and the Japan Medical Association to do more to curb the virus spread. Critics have pointed to the unusually low amount of testing in Japan-using just over half its capacity of 7500 tests a day-as well as a response that has seemingly only ramped up since the Tokyo 2020 Olympics were postponed.

Abe has said that Japan will seek to increase testing capacity to 20000 tests per day. ${ }^{3}$ People with mild symptoms are also now allowed to stay at home or in a designated hotel, rather than automatically being admitted to hospital, as is normal practice, with public health officials fearing it would overwhelm the system. Japan has just five beds per 100000 people, according to the Japanese Society of Intensive Care Medicine. Germany has 30 and Italy 12 . The health ministry anticipates as many as 700 admissions a day. ${ }^{4}$

Abe said that there were 10000 hotel rooms in Tokyo and 3000 in the western Kansai region, including Osaka, for patients with mild symptoms. Up to 800 patients will also be accommodated at the Olympic Village in Tokyo, the New York Times reported.

The northern island prefecture of Hokkaido had previously issued a month long state of emergency in February having recorded 150 cases. It lifted restrictions on 19 March. The governor of another prefecture, Aichi, said that he could declare its own state of emergency as early as 10 April. $^{5}$

Coronavirus cases in Japan top 5,000. NHK World-Japan. 9 Apr 2020. https://www3.nhk or.jp/nhkworld/en/news/20200409 28/

Japan govt to give 2 masks to every household over virus. Nippon.com. 1 Apr 2020. https: //www.nippon.com/en/news/yjj2020040101147/japan-govt-to-give-2-masks-to-everyhousehold-over-virus.html

3 Rich $\mathrm{M}$, Ueno $\mathrm{H}$, Inoue M. Japan declared a coronavirus emergency. Is It Too Late? New York Times 2020 April 7. https://www.nytimes.com/2020/04/07/world/asia/japancoronavirus-emergency.html

4 Takahashi R. Japanese ICUs understaffed and overlooked as coronavirus influx looms. Japan Times. 9 Apr 2020. https://www.japantimes.co.jp/news/2020/04/09/national/ japanese-icus-understaffed-overlooked-coronavirus-influx-looms/\#.Xo70lchKjcs

5 Aichi to declare its own state of emergency. NHK World-Japan. 9 Apr 2020. https://www3. nhk.or.jp/nhkworld/en/news/20200409_26/ 
